Japanese Journal of Physiology, 31, 657-665, 1981

\title{
Enhancement of Calorigenic Response to Cold and to Norepinephrine in Physically Trained Rats
}

\author{
Kozo Hirata and Tetsuo Nagasaka \\ Department of Physiology, School of Medicine, Kanazawa University, \\ Takara-machi, Kanazawa, Ishikawa, 920 Japan
}

\begin{abstract}
Calorigenic response to cold and to norepinephrine (NE: $4 \mu \mathrm{g} \cdot \mathrm{kg}^{-1} \cdot \mathrm{min}^{-1}$ ) in physically fit (SW) rats was compared with control (CT) and cold-acclimated (CA) rats. Physical fitness was obtained by daily 3-hr swimming in water at $36^{\circ} \mathrm{C}$ for $6-8$ weeks. Resting heart rate (HR) was significantly less in SW rats. Cold immersion (in water at $18^{\circ} \mathrm{C}$ up to the neck) increased oxygen consumption $\left(\dot{V}_{\mathrm{O}_{2}}\right)$ significantly in $\mathrm{CA}$ and $\mathrm{SW}$ compared to CT rats $(p<0.01)$. Cold immersion decreased colonic temperature $\left(T_{\mathrm{col}}\right)$ in all groups. Despite the increased calorigenic response, $\mathrm{SW}$ rats cooled as quickly as $\mathrm{CT}$ rats in cold water. Body weight and skinfold thickness were significantly less in SW than in CT rats $(p<0.01)$. Compared with CT rats, average weight of the interscapular BAT was significantly less in SW rats $(p<0.05)$. Infusion of NE significantly increased $\dot{V}_{\mathrm{O}_{2}}, T_{\text {col }}, \mathrm{HR}$ and mean aortic pressure in anesthetized rats. The increase in $\dot{V}_{\mathrm{O}_{2}}$ was significantly greater in CA $(p<0.01)$ and $\mathrm{SW}(p<0.05)$ than in CT rats. $T_{\text {col }}$ increased significantly in CA $(p<$ 0.05 ) and slightly in SW compared to CT animals.
\end{abstract}

STRøMme and HAMmel (1967) observed that physical training produced an increase in metabolic response to cold and in skin temperature on the cold exposed feet, but had no effect on metabolic or thermal responses to norepinephrine in the rat. They concluded that the calorigenic effect of norepinephrine was not increased during cold exposure in the physically trained rats. Since the beneficial changes in muscles in enhancing shivering occurred after physical training (KJELLBERG et al., 1949; Petrén et al., 1937; ReynafarJe, 1962; SChroeder et al., 1976; Siebert, 1928), the elevation of metabolic rate during cold stress was attributed mainly to an improved shivering capacity. On the other hand, CHIN et al. (1973) reported that physical training increased calorigenic response to catecholamines. Although the calorigenic response to infused norepinephrine was not measured, many other reports (GAlbo et al., 1977; HARTLEY et al., 1972; ÖSTMAN et al., 1972; Von Euler, 1974) seem to support the observation made by CHIN et al., (1973). Information about the mechanisms responsible for the increased ability to resist cold after physi-

Received for publication January 19, 1981

平田耕造，永坂鉄夫 
cal training seems to be conflicting in rats. The present study was undertaken to examine what is responsible for the increased cold tolerance in physically trained rats. To eliminate the unwarranted side effects of hyperthermia or hypothermia, the rats were trained by forced swimming in water at $36^{\circ} \mathrm{C}$ which kept their body temperature at about $37.6^{\circ} \mathrm{C}$ throughout the training period.

\section{METHODS}

Male rats of the Wistar strain, initially weighing $182 \pm 1.6 \mathrm{~g}$, were divided into 3 groups and were kept for 6-8 weeks under the following conditions. 1) Controls $(\mathrm{CT})$ : In a temperature-controlled animal room $\left(24 \pm 1{ }^{\circ} \mathrm{C}\right)$, the rats were provided with water and a commercial rat chow (Oriental MF, Oriental Yeast Co., Ltd., Tokyo) ad libitum. 2) Cold-acclimated rats (CA): In a cold room (4士 $0.5^{\circ} \mathrm{C}$ ), the rats were kept in pairs to lessen unwarranted effects of huddling (SUGANO and Nagasaka, 1979). Water and food were provided as in CT rats. 3) Physically fit rats (SW): The animals, 5 in a group at the first training, were forced to swim for $3 \mathrm{hr}$ in agitated water at $36^{\circ} \mathrm{C}$ each day (10:00-13:00), which was nearly the same temperature as described by ÖstMAN et al., (1972). The swimming tanks were $50 \times 50 \times 60 \mathrm{~cm}$ in dimension, and the water was agitated vigorously with a water pump (CP-30B, Hitachi, Tokyo). After swimming, the wet animals were quickly wiped dry with towels and were returned to the animal room in groups. Water and food were provided ad libitum. The colonic temperature $\left(T_{\mathrm{col} 1}\right)$ of the swimming rats was measured with a thermistor probe during swimming. All these animals were subjected to artificial light from 6:00 to 19:00. At the end of the 6-week acclimation and training periods, the body weights of the rats were $347 \pm$ $7 \mathrm{~g}$ for CT rats, $327 \pm 14 \mathrm{~g}$ for CA rats and $312 \pm 11 \mathrm{~g}$ for SW rats. The test was made randomly in 3 groups between 6 and 8 weeks, and the average body weights of the rats at the time of the test were $353 \pm 12 \mathrm{~g}$ for CT rats, $366 \pm 7 \mathrm{~g}$ for CA rats and $334 \pm 15 \mathrm{~g}$ for $\mathrm{SW}$ rats. The total number of rats tested in this experiment was 46.

Cold tolerance test. One day prior to the test, an individual rat was transferred to the experimental room $\left(26 \pm 1^{\circ} \mathrm{C}\right)$, where food and water were supplied ad libitum. The rat was confined individually in a $20 \times 20 \times 20 \mathrm{~cm}$ polyvinyl container whose bottom was made of stainless steel wire mesh. The lid of the container was made of plexiglass which had small holes for ventilation. The air temperature inside the container was adjusted to $28^{\circ} \mathrm{C}$. After a thermal steady state had been obtained, the rat together with the container was quickly immersed to neck level in agitated water at $18 \pm 0.3^{\circ} \mathrm{C}$ for $50 \mathrm{~min}$. The head of the rat was kept above water. The residual air in the metabolic chamber was approximately $1,200 \mathrm{ml}$ during cold immersion. The air inside the container was continuously pulled through a hole in the lid with an air pump $\left(1.5\right.$ liters $\left.\cdot \mathrm{min}^{-1}\right)$. A small fraction of the exhausted air $(180 \mathrm{ml}$. $\min ^{-1}$ ) was continuously sent to a Beckman 755 oxygen analyzer and oxygen con- 
sumption $\left(\dot{V}_{\mathrm{O}_{2}}\right)$ was calculated from partial pressure of $\mathrm{O}_{2}$ and air flow. Before measurement, 3 individual copper wires were sewed on the chest skin under local anesthesia as the electrodes for EKG. EKG were intermittently recorded on a polygraph (Biophysiograph-180, San-ei Sokki, Tokyo) and heart rate(HR) was calculated. $T_{\mathrm{co} 1}$ was recorded with a thermistor probe inserted to a depth of $7 \mathrm{~cm}$ on the polygraph. The rats subjected to $18^{\circ} \mathrm{C}$ water were not used to measure the responses to norepinephrine.

Calorigenic and cardiovascular responses to norepinephrine (NE). The rat was brought into the laboratory $\left(24 \pm 1^{\circ} \mathrm{C}\right)$ and was fitted with polyethylene catheters ( $0.6 \mathrm{~mm}$ outer diameter and $0.3 \mathrm{~mm}$ inner diameter, Imamura Rubber Co., Ltd., Tokyo) under urethane $\left(0.5 \mathrm{~g} \cdot \mathrm{kg}^{-1}\right)$ and chloralose $\left(40 \mathrm{mg} \cdot \mathrm{kg}^{-1}\right)$ anesthesia. Aortic and jugular catheters were inserted through the right carotid artery and right jugular vein, respectively. After surgery, the rat was fixed on a stainless steel wire mesh plate and immersed in a warm water bath $\left(\mathrm{ca} .36^{\circ} \mathrm{C}\right)$ to neck level to keep $T_{\mathrm{col}}$ at around $37.6^{\circ} \mathrm{C}$. Since the dose of the anesthetics was high enough to suppress muscle movement throughout the measurement, a tracheostomy was made and the rat was resuscitated with a respirator for small animals (Type 680, Harvard Apparatus, Mass.) to prevent possible depression in respiration by the anesthetics. Expired volume $(\dot{V} \mathrm{E})$ was fixed at $210 \mathrm{ml} \cdot \mathrm{min}^{-1}$ (tidal volume: $2.2 \mathrm{ml}$, frequency: $\left.96 \mathrm{~min}^{-1}\right)$. A fraction of the expired air $\left(180 \mathrm{ml} \cdot \mathrm{min}^{-1}\right)$ was sent into the Beckman $755 \mathrm{O}_{2}$ analyzer via a $200 \mathrm{ml}$ bottle reservoir which has a small leak in the cap. $\dot{V}_{\mathrm{O}_{2}}$ was calculated from $\dot{V} \mathrm{E}$ and its partial pressure of oxygen. $\mathrm{HR}$ and $T_{\mathrm{col}}$ were measured as described above. Mean aortic pressure was measured with a pressure transducer (Toyo Baldwin, Tokyo) through the aortic catheter and recorded on the polygraph. After a thermal steady state had been obtained, $l$-norepinephrinebitartrate (Wako Pure Chemical Ind., Osaka) dissolved in saline was infused for 60 min through the jugular vein with an infusion pump (LG-2, Atom Med., Tokyo). The dose of NE infused was $4 \mu \mathrm{g} \cdot \mathrm{kg}^{-1} \cdot \mathrm{min}^{-1}$. After the measurements the animals were sacrificed by an injection of saturated $\mathrm{KCl}$ solution in the right atrium through the jugular catheter, and weights of the interscapular brown adipose tissue and of the heart were measured. The skinfold thickness was measured at different sites (neck, back and axilla) with a Keys skinfold caliper in CT and SW rats. Weights of the hindleg muscles (tibialis anterior and soleus) were measured in CT and SW rats. All statistical comparisons were done by the Student $t$-test.

\section{RESULTS}

\section{Cold tolerance test}

Figure 1 illustrates the changes in $T_{\mathrm{co} 1}, \dot{V}_{\mathrm{O}_{2}}$ and $\mathrm{HR}$ during immersion in water at $18^{\circ} \mathrm{C}$ in $\mathrm{CT}, \mathrm{CA}$ and $\mathrm{SW}$ rats. Following immersion, $T_{\mathrm{col}}$ decreased in all three groups. The rate of fall in $T_{\text {col }}$ was significantly less in CA rats than in the other two groups $(p<0.05)$. Between CT and SW rats, there was no statistical difference 

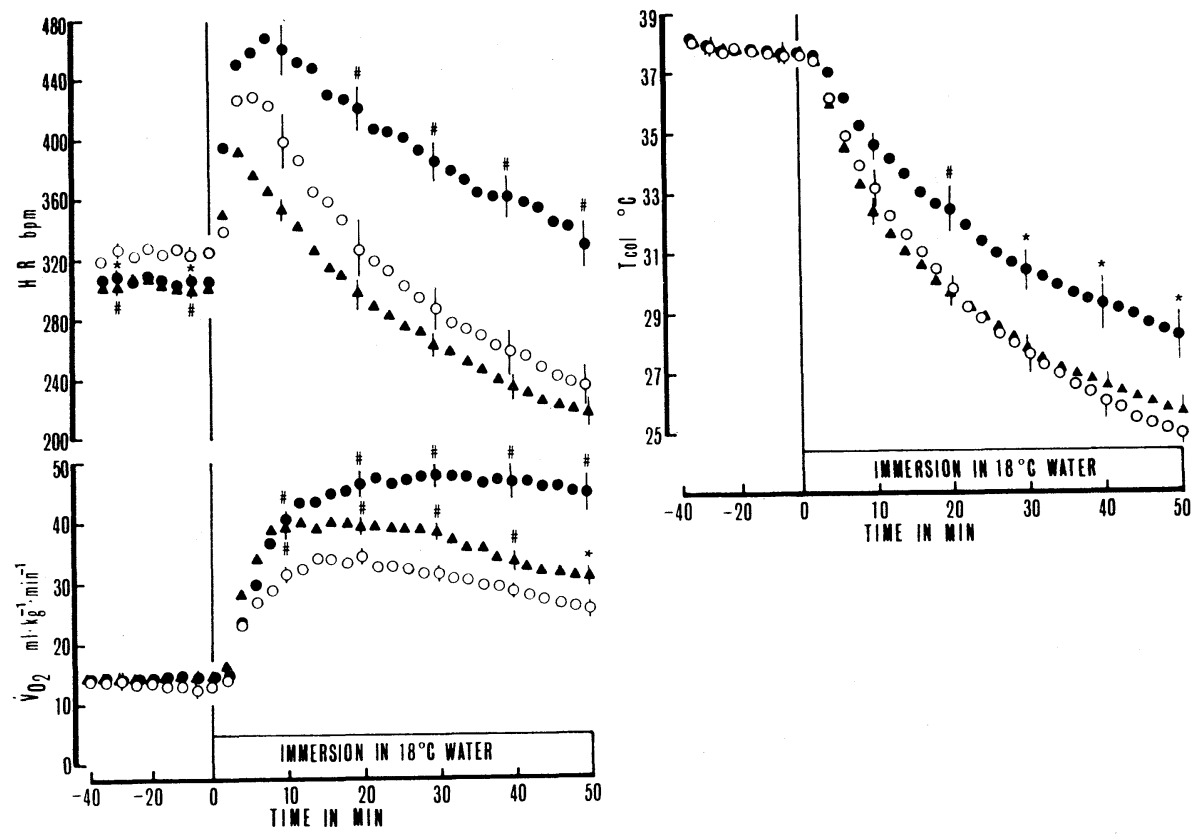

Fig. 1. Changes in $T_{\text {col }}, \dot{V}_{\mathrm{O}_{2}}$ and HR during immersion in $18^{\circ} \mathrm{C}$ water in CT (○), CA (๑) and $\mathrm{SW}(\boldsymbol{\Delta})$ rats. Values are means \pm S.E. Numbers of animals per group are $8,7,6$ for $\mathrm{CT}$, $\mathrm{CA}$ and SW rats, respectively. $* p<0.05$, $\# p<0.01$ : significant difference from the corresponding $\mathrm{CT}$ values.

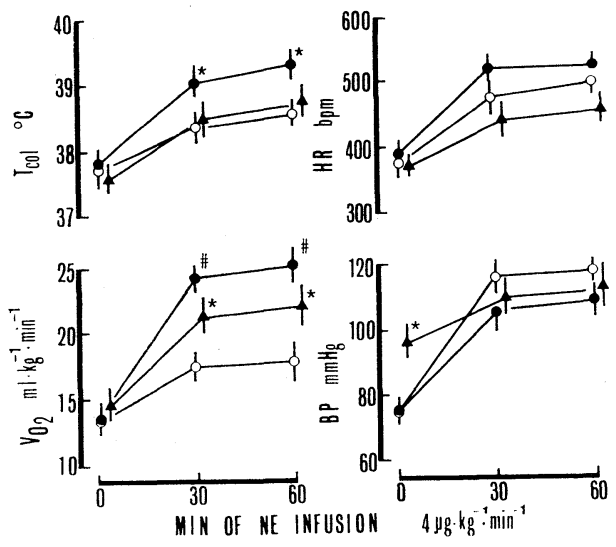

Fig. 2. Responses to infused $\mathrm{NE}\left(4 \mu \mathrm{g} \cdot \mathrm{kg}^{-1} \cdot \mathrm{min}^{-1}\right)$ in anesthetized rats. BP denotes mean aortic pressure. Symbols are the same as in Fig. 1. Values are means \pm S.E. Numbers of animals per group are $10,8,7$ for CT, CA and SW rats. ${ }^{*} p<0.05, \# p<0.01$ : significant difference from the corresponding CT values. 
in the rates of fall in $T_{\mathrm{col}} . \quad \dot{V}_{\mathrm{O}_{2}}$ increased sharply within the initial $10 \mathrm{~min}$ of immersion in all groups. The rate of increase in $\dot{V}_{\mathrm{O}_{2}}$ was greatest in CA rats and least in CT animals. In CA rats the highest $\dot{V}_{\mathrm{O}_{2}}$ was maintained for the entire period of immersion, while in SW and CT rats the level of $\dot{V}_{\mathrm{O}_{2}}$ reached 10 min after the onset of cold immersion was not maintained and gradually decreased during the rest of the 50-min immersion. $\dot{V}_{\mathrm{O}_{2}}$ was, however, significantly higher in SW rats than in CT rats $(p<0.01)$. Resting HR in SW, CA and CT rats were $301 \pm 4$, $306 \pm 5$ and $321 \pm 3 \mathrm{bpm}$ at $T_{\mathrm{a}}$ of $28^{\circ} \mathrm{C}$, respectively. The resting HR was significantly higher in $\mathrm{CT}$ rats than in $\mathrm{CA}(p<0.05)$ and $\mathrm{SW}(p<0.01)$ rats. In all groups, HR increased sharply in the initial several minutes of immersion and thereafter decreased gradually. The decrease in HR was particularly marked in CT and SW rats. In these groups, HR at the end of 50-min immersion became lower than that observed in the pre-immersion period. HR were highest in CA rats and lowest in SW rats at any time of immersion.

Calorigenic and cardiovascular responses to norepinephrine $(N E)$

Figures 2 and 3 show the effects of NE infusion $\left(4 \mu \mathrm{g} \cdot \mathrm{kg}^{-1} \cdot \mathrm{min}^{-1}\right)$ on $\dot{V}_{\mathrm{O}_{2}}$, $\mathrm{HR}, T_{\mathrm{co} 1}$ and mean aortic pressure in anesthetized rats. During the pre-infusion period, the difference in $\dot{V}_{\mathrm{O}_{2}}$ among the three groups was not significant. After infusion of NE, $\dot{V}_{\mathrm{O}_{2}}$ increased in all groups. The increases in $\dot{V}_{\mathrm{O}_{2}}$ at $60 \mathrm{~min}$ of infusion period in CA, SW and CT rats were $11.6 \pm 1.3,7.3 \pm 1.2$ and $4.4 \pm 0.8 \mathrm{ml} \cdot \mathrm{kg}^{-1}$ $\cdot \mathrm{min}^{-1}$, respectively. The rate of increase in $\dot{V}_{\mathrm{O}_{2}}$ was greatest in CA rats and least in CT animals, and the difference in $\dot{V}_{\mathrm{O}_{2}}$ between these two groups was statistically significant $(p<0.01)$. The increase in $\dot{V}_{\mathrm{O}_{2}}$ was also significantly higher in $\mathrm{SW}$ rats than in CT rats $(p<0.05)$. The increase in $T_{\text {col }}$ with NE infusion in CA, SW and $\mathrm{CT}$ rats were $1.50 \pm 0.22,1.20 \pm 0.20$ and $0.83 \pm 0.15^{\circ} \mathrm{C}$, respectively, at $60 \mathrm{~min}$ of
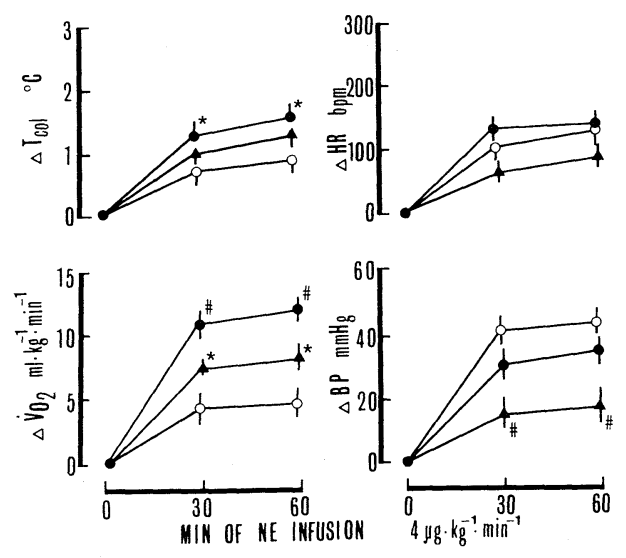

Fig. 3. Increases in response to NE $\left(4 \mu \mathrm{g} \cdot \mathrm{kg}^{-1} \cdot \mathrm{min}^{-1}\right)$. Symbols are the same as in Fig. 1 . Values are means \pm S.E. $\quad{ }^{*} p<0.05, \# p<0.01$ : significant difference from the corresponding $\mathrm{CT}$ values. 


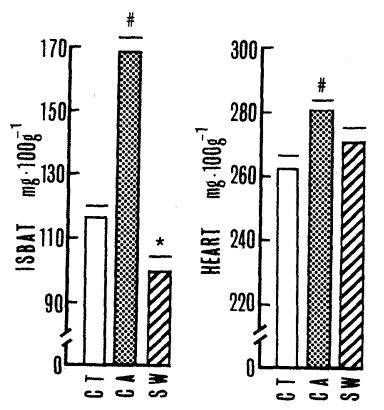

Fig. 4. Weight of the interscapular brown adipose tissue (ISBAT) and the heart expressed as $\mathrm{mg}$ per $100 \mathrm{~g}$ of body weight in CT, CA and SW rats. Bars represent means \pm S.E. ${ }^{*} p<0.05$, $\# p<0.01$ : significant difference from the corresponding $\mathrm{CT}$ values.

infusion period. The increase in $T_{\text {со1 }}$ was significantly greater in CA rats than in $\mathrm{CT}$ rats $(p<0.05)$. There was no significant difference in $T_{\text {col }}$ between $\mathrm{SW}$ and CT rats.

Under anesthesia, HR were nearly the same in three groups in the pre-infusion period. With infusion of NE, HR increased in all groups, but the rates of increase in HR were greatest in CA rats and least in SW rats. Compared with the increase in CT rats, the increases in HR in CA and SW rats were not statistically significant. Mean aortic pressure was significantly higher in SW rats $(p<0.05)$ than in the other two groups in the pre-infusion period. With infusion of NE, mean aortic pressure increased in all groups, but the pressor response to NE was significantly less in SW rats. As shown in Fig. 4, the average weights of the heart and the interscapular brown adipose tissue (BAT) significantly increased in CA rats $(p<0.01)$. In SW rats, the average heart weight increased slightly, but not significantly. The BAT decreased significantly in SW rats $(p<0.05)$. The average skinfold thicknesses in $\mathrm{CT}$ and SW rats were $12.7 \pm 0.30$ and $11.2 \pm 0.36 \mathrm{~mm}$, respectively $(p<0.01)$. The weight of hindleg muscles increased significantly in SW rats (tibialis anterior: $195.2 \pm 3.7 \mathrm{mg} \cdot(100 \mathrm{~g} \mathrm{~b} . \mathrm{w} .)^{-1}$ in $\mathrm{SW}$ rats as opposed to $176.4 \pm 2.2 \mathrm{mg} \cdot(100 \mathrm{~g} \mathrm{~b} . \mathrm{w} .)^{-1}$ in CT rats $(p<0.001)$ : soleus: $39.6 \pm 0.8 \mathrm{mg} \cdot(100 \mathrm{~g} \mathrm{~b} . \mathrm{w} .)^{-1}$ as opposed to $35.7 \pm$ $0.9 \mathrm{mg} \cdot(100 \mathrm{~g} \mathrm{b.w})^{-1}$ in CT rats $\left.(p<0.01)\right)$. These parameters in CA rats were not measured in this study.

\section{DISCUSSION}

Our SW rats were physically trained by daily $3-\mathrm{hr}$ swimming at $36^{\circ} \mathrm{C}$ for $6-8$ weeks. According to HARRI and VALTOLA (1975), cold tolerance greatly increased in rats repeatedly forced to swim in cool water at $30^{\circ} \mathrm{C}$. In these rats, however, body temperature decreased significantly while swimming. It is difficult to study the effects of physical training per se on cold tolerance with such animals. Therefore, the water temperature of $36^{\circ} \mathrm{C}$ was selected to keep the core temperature of a rat at a normothermic level (about $37.6^{\circ} \mathrm{C}$ ) throughout swimming in this study, as described by ÖstMAN et al. (1972). After the end of the training period, the resting HR in unanesthetized SW rats was significantly lower than CT rats. Many 
workers (BARNARD et al., 1976; BolTER et al., 1973; Crews and Aldinger, 1967; TIPTON, 1965) suggested that prolonged periods of endurance training produced a resting bradycardia, which can be employed as a criterion of physical fitness. Since resting HR was significantly lower $(p<0.01)$, it was considered that $\mathrm{SW}$ rats in this experiment were apparently physically fit animals.

SW rats cooled as quickly as CT rats in agitated water at $18^{\circ} \mathrm{C}$ (Fig. 1). However, it would appear that the fall in $T_{\text {col }}$ in CA rats was greatly retarded. Following cold immersion, $\dot{V}_{\mathrm{O}_{2}}$ was significantly higher in $\mathrm{SW}$ rats than in CT animals. At the same $T_{\text {col }}$, for instance at $34^{\circ} \mathrm{C}, \dot{V}_{\mathrm{O}_{2}}$ was significantly higher in $\mathrm{SW}$ rats $(36.8$ $\left.\pm 1.5 \mathrm{ml} \cdot \mathrm{kg}^{-1} \cdot \mathrm{min}^{-1}\right)$ than in CT animals $\left(28.5 \pm 1.0 \mathrm{ml} \cdot \mathrm{kg}^{-1} \cdot \mathrm{min}^{-1}\right)(p<0.01)$ indicating that physical training produced an increase in metabolic response to cold in the rat. Therefore, the rather high rate of fall in body temperature in SW rats could not be attributed to a decrease in calorigenic response to cold. Average body weight of SW rats at the date of test was $334 \mathrm{~g}$, which was approximately 19 and $32 \mathrm{~g}$ less than that of CT and CA rats, respectively. The skinfold thickness was significantly less in SW rats than in CT rats $(p<0.01)$. The rather quick fall in body temperature after cold immersion might be largely attributable to the lower body mass and decreased body insulation of SW rats. Since water has a high thermal conductivity, the $18^{\circ} \mathrm{C}$ water must have been cold for the rats. Whether the same result would be obtained in cool air or during mild cold water immersion needs further investigation. HR increased quickly to certain higher levels within several minutes of cold immersion and thereafter began to decrease. The decrease in HR seems to be dependent on the decrease in body temperature, but the relationship between $T_{\text {col } 1}$ and HR was different in the physically fit rats compared with those in the other two groups.

Infusion of NE increased $\mathrm{HR}$ and $\dot{V}_{\mathrm{O}_{2}}$ in anesthetized rats (Figs. 2 and 3). The metabolic increase was significantly greater in SW $(p<0.05)$ and CA $(p<0.01)$ rats than in CT animals. $T_{\text {col }}$ increased significantly in CA $(p<0.05)$ and slightly in SW compared to CT rats. These results suggest that physical training by repeated swimming can enhance metabolic response to NE in the rat. Body temperature was kept at about $37.6^{\circ} \mathrm{C}$ and shivering was not observed throughout the test. The rise in $\dot{V}_{\mathrm{O}_{2}}$ with infusion of NE may be largely attributed to nonshivering thermogenesis. It is well known that the increased metabolic capacity of the coldacclimated animals is accompanied by an increased mass of BAT (FOSTER and Frydman, 1978; Heldmaier, 1974; SMith and Horwitz, 1969). Hull and SEGALL (1965) partly excised the BAT in newborn rabbits and found that the calorigenic response to norepinephrine was proportional to the amount of tissue remaining. In CA rats in the present study, the mass of the interscapular BAT increased significantly $(p<0.01)$ and the enhanced calorigenic response to cold and infused norepinephrine seemed to be proportional to the increased mass of this tissue. However, the mass of the interscapular BAT significantly decreased after the daily 3-hr swimming for 6-8 weeks $(p<0.05)$. The participation of the BAT seemed to 
be less in the increased calorigenic response to NE in our SW rats. SW rats had a significantly large mass of hindleg muscles (tibialis anterior, $p<0.001$; soleus, $p<0.01$ ). Whether this increased mass of skeletal muscles contributed to the enhanced calorigenic response to NE is not known. The conclusion should be reserved until the metabolic activities of BAT and skeletal muscles have been measured.

This work was supported in part by the Grant-in-Aid for Scientific Research from the Ministry of Education, Science and Culture of Japan (Grant No. 487040 and 548106).

\section{REFERENCES}

BARnard, R. J., CoRre, K. K., and CHO, H. (1976) Effect of training on the resting heart rate of rats. Eur. J. Appl. Physiol., 35: 285-289.

Bolter, C. P., Hughson, R. L., and Crits, J. B. (1973) Intrinsic rate and cholinergic sensitivity of isolated atria from trained and sedentary rats. Proc. Soc. Exp. Biol. Med., 144: 364-367.

Chin, A. K., Seaman, R., and Kapileshwarker, M. (1973) Plasma catecholamine response to exercise and cold adaptation. J. Appl. Physiol., 34: 409-412.

Crews, J. and Aldinger, E. E. (1967) Effect of chronic exercise on myocardial function. Am. Heart J., 74: 536-542.

Foster, D. O. and Frydman, M. L. (1978) Nonshivering thermogenesis in the rat. II. Measurement of blood flow with microspheres point to brown adipose tissue as the dominant site of the calorigenesis induced by noradrenaline. Can. J. Physiol. Pharmacol., 56: 110-122.

Galbo, H., Richter, E. A., Holst, J. J., and Christensen, N. J. (1977) Diminished hormonal responses to exercise in trained rats. J. Appl. Physiol.: Respir. Environ. Exercise Physiol., 43: 953-958.

Harri, M. N. E. and Valtola, J. (1975) Comparison of the effects of physical exercise, cold acclimation and repeated injections of isoprenaline on rat muscle enzymes. Acta Physiol. Scand., 95: 391-399.

Hartley, L. H., Mason, J. W., Hogan, R. P., Jones, L. G., Kotchen, T. A., Mougey, E. H., Wherry, F. E., Pennington, L. L., and Ricketts, P. T. (1972) Multiple hormonal responses to prolonged exercise in relation to physical training. J. Appl. Physiol., 33: 607-610.

HeldmaieR, G. (1974) Cold adaptation by short daily cold exposures in the young pig. $J$. Appl. Physiol., 36: 163-168.

Hull, D. and Segall, M. M. (1965) The contribution of brown adipose tissue to heat production in the new-born rabbit. J. Physiol. (Lond.), 181: 449-457.

KJEllbERG, S. R., RudHE, U., and SJöSTRAND, T. (1949) Increase of the amount of hemoglobin and blood volume in connection with physical training. Acta Physiol. Scand., 19: 146-151.

Östman, I., SJöstrand, N. O., and Swedin, G. (1972) Cardiac noradrenaline turnover and urinary catecholamine excretion in trained and untrained rats during rest and exercise. Acta Physiol. Scand., 86: 299-308.

Petrén, T., Suöstrand, T., and Sylv́en, B. (1937) Der Einfluss des Trainings auf die Häufigkeit der Capillaren in Herz- und Skeletmuskulatur. Arbeitsphysiologie, 9: 376-386.

REYNAFARJE, B. (1962) Myoglobin content and enzymatic activity of muscle and altitude adaptation. J. Appl. Physiol., 17: 301-305.

Schroeder, W., Treumann, F., Rathscheck, W., and Müller, R. (1976) Muscle- $p_{\mathrm{O} 2}$ in trained and untrained non-anesthetized guinea pigs and in men. Eur. J. Appl. Physiol., 35: 215221 . 
SIEBERT, W. W. (1928) Untersuchungen über Hypertrophie des Skelettmuskels. $\quad$ Z. Klin. Med., 109: 350-359.

Smith, R. E. and Horwitz, B. A. (1969) Brown fat and thermogenesis. Physiol. Rev., 49: 330425.

Strømme, S. B. and HAMmel, H. T. (1967) Effects of physical training on tolerance to cold in rats. J. Appl. Physiol., 23: 815-824.

Sugano, Y. and Nagasaka, T. (1979) Effect of huddling on heat losses in infant dogs. $J$. Physiol. Soc. Jpn., 41: 145-147.

Tipton, C. M. (1965) Training and bradycardia in rats. Am. J. Physiol., 209: 1089-1094.

VON EULER, U. S. (1974) Sympatho-adrenal activity in physical eyercise. Med. Sci. Sports, 6: 165-173. 